\title{
Influence of Transformational Leadership and Work Engagement On Innovative Behavior
}

\author{
Nafiah Ariyani ${ }^{1}$, Sri Hidayati ${ }^{2}$
}

\begin{abstract}
Innovative behavior, employee engagement and transformational leadership are critical variables that should be the focus of every organization's this era of rapid technological change. This study aims to determine the effect of transformational leadership and work engagement on innovative behavior in the banking industry in Indonesia. The technique sampling is purposive sampling, so the numbers of samples are 378 people. The Data analysis technique is multiple linear regression analysis. The results show that transformational leadership and work engagement have a significant and positive effect on innovative behavior, in which work engagement as a mediating variable will to the positive influence of transformational leadership on innovative behavior. These findings suggest that it is necessary to apply transformational leadership styles and increase employee engagement to improve innovative employee behavior.
\end{abstract}

Keywords: innovative behavior, transformational leadership, work engagement

\begin{abstract}
Abstrak. Perilaku inovatif, keterikatan karyawan terhadap organisasi (work engagement) serta kepemimpinan transformasional merupakan variabel kritis yang harus menjadi fokus perhatian setiap organisasi agar berhasil di era perubahan teknologiyangsangatcepatsekarang ini. Penelitian ini bertujuan untuk mengetahui pengaruh kepemimpinan transformasional dan work engagement terhadap perilaku inovatif karyawan di industri perbankan di Indonesia. Jumlah sampel penelitian ini 378 orang yang diambil dengan metode purposive sampling. Teknik analisa data yang digunakan dalam penelitian ini adalah analisa regresi linier berganda. Hasil penelitian menunjukkan bahwa kepemimpinan transformasional dan work engagement berpengaruh signifikan dan positif terhadap perilaku inovatif dimana work engagement berperan sebagai variabel pemediasi terhadap pengaruh positif kepemimpinan transformasional pada perilaku inovatif. Temuan ini menunjukkan bahwa untuk meningkatkan perilaku inovatif karyawan perlu diterapkan gaya kepemimpinan transformasional dan meningkatkan keterikatan karyawan terhadap organisasi.
\end{abstract}

Kata kunci: perilaku inovatif, kepemimpinan transformasional, work engagement

\section{How to Cite:}

Ariyani, N., \& Hidayati, S. (2018). Influence of Transformational Leadership and Work Engagement on Innovatiove Behavior. Etikonomi: Jurnal Ekonomi. Vol. 17 (2): 275 - 284. doi: http//dx.doi.org/10.15408/etk.v17i2.7427. 


\section{Introduction}

The relatively rapid change in the business world accompanied by rapid technological developments as well as unpredictable economic trend changes; the companies have to quickly make adjustments for its business practices (Afsar et al., 2014). One of them is with adopt new knowledge and apply it that is known as innovation. Jong and Hartog (2010), Park, et al., (2013) stated that innovation became a very critical factor in determining the success or failure of a company. Kroes (2015) emphasized that innovation is a form of work behavior that is highly demanded by the company for the success of its employees and companies as well.

The innovation process requires full employee engagement to maintain the continuity, sustainability, and growth of the company created through the creative development and implementation of new ideas (Rao and Weintraub, 2013). According to Johnston and Bate (2013), maximizing the potential of employee innovation is a priority that must be done by every organization, so it formed the innovative work behavior. Spiegelaere, et al., (2012) stated that innovative behavior is the behavior of employees who continually introduce and/ or apply a new idea, process, product or procedure that is relevant and beneficial to the unit both in his role as individuals, group, or organization. The innovative behavior can create competitive advantage and work achievement satisfaction through differentiation and improvement in products and services (Park et al., 2013).

Kroes (2015), Zhang and Bartol (2010) stated that innovative behavior at every organization level either directly or indirectly requires the support of leaders. With good managerial skills leaders can direct the behavior of their subordinates. Thus the leader has a huge role and should focus on the establishment of employee innovative behavior (Yuan and Woodman, 2010). According to Seppala (2016), to cultivate innovation behavior, a leader must do the following three things: inspire, spread kindness and pay attention to the rights related to the personal lives of employees, such as health, happiness, and welfare.

Bass (1985) in Seppala (2016) stated that among the various types of leadership, transformational leadership is the right type to form innovative behavior. This thought is in line with of Jong and Hartog (2010) stated that a transformational leader could stimulate innovative behavior. The transformational leaders who have a new perception of the future will encourage employees to reach a new future following what it describes (Kroes, 2015). The transformational leaders encourage employees to involve in work or organization, solidarity, commitment, developing potency, and improve performance. An employee who gets the support, inspiration, and guidance from his leader, will get more challenging work experience, involve more profoundly and more satisfying, all of that will affect on the high involvement of employees on the task and work (Tims et al., 2011).

Besides discussing the necessity of transformational leaders and innovation, Kroes (2015) stated that to improve the innovative behavior is required special attention especially to work engagement, namely employees who have favorable conditions in their heart, aligned with that in their mind driven by passion, dedication, and solemnity. Employees with work engagement will provide more contributions, especially in generating ideas for the better development of the company and producing initiatives that will have an impact on innovation. 
Formally work engagement has three essential components, namely: logical commitment, emotional commitment, and remarkable effort (discretional) (Macey and Schneider, 2008). The indication of work engagement can see from how committed the employees to keep working on the company, how far the employees felt proud of the company and motivated to work on the company, as well as how far the employees are willing to give the best effort in achieving company goals. According to Park et al., (2013), when there is work engagement, someone will feel positive emotions that will encourage to more open creativity and thinking and ideas to apply them. The energy that generated by the work engagement will encourage companies to innovate, so that will make employees more proactive and have responsibility.

Concerning innovation, work engagement will improve the transformational leadership role towards innovative behavior (Harter and Adkins, 2015). Tims et al., (2011) stated that transformational leadership is critical in improving work engagement and employee performance. The style of transformational leadership becomes a role model for employees to behave innovatively (Baker et al., 2011). Innovative behavior is increasing when employees have work engagement (Reuvers et al., 2008).

PT Bank OCBC NISP Tbk is one of the largest and oldest banks in Indonesia, which from 2012 until 2017 was 0 n 11th ranked. The rating is still below the management target of becoming a "top ten bank." Various efforts have been made, including improvements regarding technology, infrastructure, and policy, but these efforts are less than optimal. This phenomenon seen in the financial performance shown by net interest margin (NIM) is below the industry average NIM, which is $4.6 \%$, where the industry NIM of 5.59\%. Similarly, BOPO level (operational cost compared to operating income) is much lower than the industry's BOPO level of $21.30 \%$ while the industry's BOPO is $82.23 \%$ (Banking Industry Profile Report 2016 and Financial Performance Report of PT Bank OCBC NISP Tbk - First Semester of 2016). The low percentage of BOPO shows that the operational cost at PT Bank OCBC NISP Tbk is high but not balanced with operational income. Low productivity and small non-interest income, requires the management of PT Bank OCBC to take strategic steps, one of which is to encourage innovation from internal employees.

Over the past three years, PT Bank OCBC NISP Tbk has launched several innovations in services and products as shown in Table 1, but it is frequently too late. As result services or similar products have been launched in advance by other banks, for example in digital-based services, such as digital banking (internet banking, mobile banking), digital branches (digital branch services) and virtual accounts.

Table 1. Innovation Activities at PT Bank OCBC NISP Tbk

\begin{tabular}{llll}
\hline Year/Activities & 2014 & 2015 & 2016 \\
\hline The correction of sevices process & 29 & 34 & 42 \\
The launching of new products & 28 & 28 & 23 \\
\hline
\end{tabular}

Source: PT Bank OCBC NISP Tbk (2017) 
Overall innovative activities that have carried out indeed were an increase, but this is not comparable with the total number of employees that reached 6,000 people. One of the obstacles to the application of innovation in PT Bank OCBC NISP Tbk is the factor of employee involvement in the innovation process is still low. This fact is allegedly related to the type of leadership that is still conventional so that the innovation process requires a long stage due to the attitude of some leaders who are less flexible and low work engagement. Banking as one of the modern services industry is demanded to have the creativity that comes from employees. This fact is in line with the statement of Leiter and Bakker (2010) that to succeed a modern company expected the employees to be proactive and show initiative, responsible for their professional development and commit to high-quality performance standards. The company needs energetic and dedicated employees, namely employees with profoundly working engagement levels. Based on the matters mentioned before, this research intends to test the positive influence of transformational leadership and the role of mediating work engagement on the influence of transformational leadership on innovative employee behavior in PT Bank OCBC NISP Tbk. Research with this theme is still rare in Indonesia, especially in the banking industry. Furthermore, the use of work engagement as mediation variables in explaining the effect of transformational leadership variables on innovation behavior is another novelty of this study.

\section{Method}

This research used causality paradigm to prove the relationship of cause and effect among several variables, namely transformational leadership, work engagement and innovative behavior. This research was designed to prove the effect of transformational leadership towards innovative behavior variable that works engagement as a mediator variable.

This research uses the questionnaire method to collect data. The questionnaire designed as a closed questionnaire. The measurement scale used a five-point Likert scale (one = strongly disagree, five = strongly agree). Likert scale is a scale used to measure the attitude of opinions and perceptions of a person or group about an indication or phenomenon (Cooper and Schindler, 2014). Before using it, questionnaires have tested with content validity that was done with face validity techniques by experts and declared passed. While the reliability test carried out by using Cronbach's Alpha, the result is reliable.

The population of this research is all employees of PT Bank OCBC NISP Tbk. Sampling was done by non-probabilistic sampling method, with purposive sampling technique. To decide the size of samples used Slovin formula so that the number of samples obtained from 378 respondents.

The data analysis in this research did by a statistical method. Statistical methods that used are descriptive statistics and inferential statistics. Descriptive statistics are used to describe the tendency of centralized data and to know the relationship between variables studied. Descriptive statistics that used in this research were mean, deviation standard and correlation analysis.

Inferential statistics are used to test hypotheses and significance of research outcome. 
The statistical technique that used is multiple linear regressions to test Hypothesis1 and Hypothesis2. Multiple linear regression equation from this research can write as follows:

$$
I B=\alpha+\beta_{1} T L+\beta_{2} W E+\varepsilon
$$

Where: IB is Innovative behavior; TL is Transformasional leadership; WE is Work engagement

\section{Result and Discussion}

The descriptive statistical analysis is performed to provide an overview of research variables consisting of Innovative Behavior (Y), Inferential Leadership (X1) and Work Engagement (X2) through the mean, the standard of deviation and correlation coefficient. The full descriptive statistics can see in Table 2.

Table 2. The Result of Descriptive Statistical Test

\begin{tabular}{lccccc}
\hline \multicolumn{1}{c}{ Variable } & Mean & Dev. Std. & $\begin{array}{c}\text { Transformational } \\
\text { Leadership }\end{array}$ & Work Engagement & $\begin{array}{c}\text { Inovative } \\
\text { Behavior }\end{array}$ \\
\hline $\begin{array}{l}\text { Transformational } \\
\text { Leadership }\end{array}$ & 3,60 & 0,66 & - & \\
Work Engagement & 3,71 & 0,55 & $0,41^{* *}$ & - & - \\
Inovative Behavior & 3,73 & 0,48 & $0,38^{* *}$ & $0,58^{* *}$ & - \\
\hline
\end{tabular}

Source: data processed (2017)

Based on Table 2, it can see that the three variables that studied have to mean ranging from 3.60 to 3.7 with the highest value is an innovative behavior variable that has a deviation standard is 0.48 . From this founding, data can conclude that innovative behavior transformational leadership and work engagement in PT. Bank OCBC NISP Tbk. are running well but not maximized.

The result of correlation analysis showed that transformational leadership variable with work engagement variable correlated positively and significantly with correlation coefficient value $(r)$ equal to $=0,61 ; \rho<0.01$. Between transformational leadership variables with innovative behavioral variables correlated positively and significantly with correlation coefficient value $(r)$ of $0.65 ; \rho<0.01)$. Similarly, the relationship between work engagement variables and innovative behavior variables is positive and significant with the correlation coefficient value of $(r)$ of $0.68 ; \rho<0.01)$. When viewed from the strength of the relationship among variables, there is a relationship between the three variables that studied.

Inferential statistical methods are used to test the proposed hypothesis. The method used is regression analysis. Regression analysis results shown in Table 3. 
Nafiah Ariyani. Influence of Transformational Leadership and Work Engagement

Table 3. Regression Analysis Results

\begin{tabular}{|c|c|c|c|c|c|c|}
\hline \multirow{2}{*}{$\begin{array}{l}\text { Dependent Variable } \\
\text { Independent Variable }\end{array}$} & \multicolumn{3}{|c|}{ Innovative Behavior } & \multicolumn{3}{|c|}{ Work Engagement } \\
\hline & $\beta$ & $\mathbf{t}$ & $\rho$ & $\beta$ & $\mathbf{t}$ & $\rho$ \\
\hline Transformational Leadership & 0,378 & 8,719 & 0,001 & & & \\
\hline $\mathrm{R}^{2}$ & & 0,143 & & & & \\
\hline Transformational Leadership & & & & 0,412 & 9,643 & 0,001 \\
\hline $\mathrm{R}^{2}$ & & & & & 0,169 & \\
\hline Work Engagement & 0,582 & 15,288 & 0.001 & & & \\
\hline $\mathrm{R}^{2}$ & & 0,339 & & & & \\
\hline Transformational Leadership & 0,167 & 4,057 & 0,001 & & & \\
\hline Work Engagement & 0,514 & 12,498 & 0,001 & & & \\
\hline$R^{2}$ & & 0,362 & & & & \\
\hline
\end{tabular}

Source: data processed (2017)

The result of regression analysis on transformational leadership with innovative behavior shows that transformational leadership positively influences to innovative behavior. This result can see from the value of regression coefficient $(\beta)$ of 0.378 . The result of this analysis is significant that indicated by t value $=8,719$ with significance value $(\rho)<0,01.14 .3 \%$ can explain the variations of innovative behavior variables through transformational leadership variables $(\mathrm{R} 2=0.143)$. Based on these results Hypothesis I that states that transformational leadership has a positive effect on innovative behavior supported.

The results can state that the higher the level of transformational leadership, the higher the employee's innovative behavior otherwise if the level of transformational leadership is low then the innovative behavior of employees will also be low as well. Under low transformational leadership conditions that leaders do not show enthusiasm in supporting employees, they will not have the courage to release ideas and opinions because the leaders are not able to appreciate the ideas and opinions of employees. The results of this research are consistent with the research of Kroes (2015), which stated that transformational leadership influences innovative behavior, and in line with research conducted by Afsar, et al. (2014), who found that there was a positive relationship between transformational leadership and innovative behavior.

Performing regression analysis partially and simultaneously analyzes the role of mediating work engagement variables on leadership variables and innovative behavior. The results of the regression analysis are presented in Table 3 which can explain as follows. Partially, transformational leadership variables have a positive and significant influence on work engagement that shown by regression coefficient value $(\beta)$ of 0.412 ; value $t=9,643 ; \rho=0.001 .16 .90 \%$ can explain variations in work engagement variables by transformational leadership $(\mathrm{R} 2=0.169)$. Work engagement variables have a positive and significant influence on the innovative behavior that 
is shown by the regression coefficient $(\beta)$ of $0.582 ; \mathrm{t}=15.288 ; \rho=0.001 .33,90 \%$ can explain the innovative behavior variation by work engagement $(\mathrm{R} 2=0,339)$.

Test results on the effect of transformational leadership and work engagement variables simultaneously on innovative behavior show transformational leadership take effect positively and significantly to innovative behavior $(\beta=0,167 ; t=4,057 ; \rho=0,001)$ while work engagement have positive and significant influence on innovative behavior $(\beta=0,514 ; \mathrm{t}=12,498 ; \rho=$ 0.001). 36.20\% can explain innovative behavior variation through transformational leadership and work engagement $(\mathrm{R} 2=0.362)$. The significant effect of transformational leadership on this analysis decreases as the work engagement variable acts as a mediating variable. According to Baron and Kenny (1986) with the decreasing influence of transformational leadership on innovative behavior suggests that work engagement acts as a partial mediator on the influence of transformational leadership on innovative behavior. Based on the regression test it can be concluded that the hypothesis supported. This result can state that due to the mediating factor of work engagement, the direct impact of transformational leadership on innovative employee behavior becomes smaller, but it remains significant. The results of this analysis indicate that there is an effect of mediating work engagement on the influence of transformational leadership on innovative behavior so that the existence of work engagement is necessary for developing the appearance of innovative behavior.

Overall the results of this research indicate that transformational leaders will act as role models (idealized influence), which will become an example for employees in their daily actions. The role of transformational leaders as motivators and inspirations (inspiration motivation) for employees, can be shown with the spirit and encouragement of leaders that will affect employee spirit of work. A transformational leader can encourage team members to be innovative and creative (intellectual stimulation) and to pay particular attention to the needs of each in proportion to achievement and development (individual consideration). These four things affect the employee spirit of work (vigor), high dedication and employee attachment (absorption) on the job. When employees have a high level of work engagement, as indicated by these three factors, it creates a conducive environment, so that the role of transformational leadership towards innovative behavior will increase.

The results of this study reinforce previous research conducted by Jong and Hartog (2010) and Kroes (2015) that emphasized the importance of applying the transformational leadership type to every organizational leader to foster innovative employee behavior along with strong management commitment in improving work engagement. This is consistent with the results of the research of Tims et al., (2011), which states that the development of transformational leadership must start from the leadership of the organization through the creation of an inspiring vision of the future, motivating team members to engage and provide the best energy to achieve that vision, directly under challenging jobs, open to answer team members' questions, build relationships and trust with team members. Besides that, the transformational leadership must help team members to grow and develop as intelligent and responsive individuals and have closeness to their organization and work. The results of the study became useful contributions to organizational management amid rapid technological changes that impacted the way organizations work that require immediate anticipation. 


\section{Conclusion}

Some conclusions can obtain from the results of data analysis and discussion. First, the research found that transformational leadership had a positive and significant effect on innovative behavior. Second, work engagement mediates the positive effect of transformational leadership on innovative behavior partially. This conclusion can say that the transformational leadership style would stimulate the innovative behavior of employees, provide space for team members to make changes and new things, will foster employee confidence to improve work engagement and innovative behavior.

From the results of this research, companies that seek to improve innovative employee behavior can do by focusing on applying transformational leadership styles. Transformational leadership proves to improve employee's innovative behavior, which will ultimately give a positive effect on the growth and sustainability of the company. Choosing managers who have particular skills and transformational characteristics can be a company strategy. To develop the interpersonal skills that a transformational leader desperately needs, training with the theme of enhancing emotional intelligence, is one example that can do. Emotional intelligence is needed by the leader to appreciate the potential of others and mobilize others to achieve their vision.

On the other hand, companies should provide training to employees to expand their insights by bringing in practitioners with experience in handling multinational companies. It can help employees to think globally and complexly, so they can understand the complexity of the environment, respect the opinions of others and have a more open mind.

The results of this research also show that work engagement improves the role of transformational leadership towards innovative behavior. To improve work engagement can be done by giving attention to employees both to the aspects of their performance and personal things as well. Companies can arrange a comfortable and attractive work environment, giving rewards to outstanding employees or engage employees in social activities. This approach will arise a positive attitude from employees to be dangerous in completing their work.

\section{References}

Afsar, B., Badir, Y., \& Bin Saeed, B. (2014). Transformational Leadership And Innovative Work Behavior. Industrial Management and Data System. Vol. 114 (8): 1270-1300. doi: https://doi.org/10.1108/IMDS-05-2014-0152.

Baker, A.B., Demerouti, E., and Ten Brummelhuis, L.L. (2011). Work Engagement, Performance, and Active Learning: The Role of Conscientiousness. Journal of Vocational Behavior, 80, 555 - 564 .

Cooper, D.R., \& Schindler, P. S. (2014). Business Research Methods, $12^{\text {th }}$ edition, New York: McGraw-Hill.

Harter, J., and Adkins, A. (2015). What Great Manager Do To Engage Employee. Harvard Business Review, April 02, 2015. Available in https://hbr.org/2015/04/what-greatmanagers-do-to-engage-employees, accessed on $29^{\text {th }}$ October 2016. 
Johnston, R.E., and Bate, J.D. (2013). The Power of Strategy Innovation: A New Way of Linking Creativity and Strategic Planning to Discover Great Business Opportunities. New York: Amacom.

Jong, J. P. J., \& Hartog, D. N. (2010). Measuring Innovative Work Behaviour. Creativity and Innovation Management. Vol. 18(1):23-36. doi:https://doi.org/10.1111/j.1467-8691.2010. 00547.x

Kroes, B. (2015). The Relationship Between Transformational Leadership and Innovative Work Behavior: The Role of Self-Efficacy and The Effect of Perceived Organizational Support on Innovative Work Behavior. (Unpublished Dissertation). Netherlands: Tilburg University.

Leiter, M. P., \& Bakker, A.B. (2010). Work Egagement: Introduction. In Bakker, A. B. (Ed). Work Engagement: A Handbook Of Essential Theory And Research. New York: Psychology Press.

Macey, W. H., \& Schneider, B. (2008). The Meaning of Employee Engagement, Industrial and Organizational Psychology. Vol. 1(1): 3-30. doi: https://doi.org/10.1111/j.1754-9434.2007. 0002.x.

Park, Y. K., Song, J. H., Yoon, S. W., \& Kim, J. (2013). Learning Organization and Innovative Behavior: The Mediating Effect of Work Engagement. European Journal of Training and Development. Vol. 38(1/2): 75-94. doi: https://doi.org/10.1108/EJTD04-2013-0040.

Reuvers, M., Van Engen, M. L., Vinkenburg, C. J., \& Wilson-Evered, E. (2008). Transformational Leadership And Innovative Work Behaviour: Exploring The Relevance Of Gender Differences. Creativity and Innovation Management. Vol. 17(3): 227-244. doi: https://doi.org/10.1111/j.1467-8691.2008.00487.x.

Rao, J., \& Weintraub, J. (2013). How Innovative Is Your Company's Culture?, MIT Sloan Management Review. Vol. 54(3): 29-37.

Seppala, E. (2016). To Motivate Employees, Do 3 Things Well. Harvard Business Review, Available in January 04, 2016. Available in https://hbr.org/2016/01/to-motivateemployees-do-3-things-well. accesed on 29 ${ }^{\text {th }}$ July 2016.

Shaufeli, W.B., and Bakker, A.B. (2010). Defining And Measuring Work Engagement: Bringing Clarity To The Concept. In Bakker, A.B. dan Leiter, M.P. (Ed). Work Engagement: A Handbook of Essential Theory and Research. New York: Psychology Press.

Spiegelaere, S., Van Gyes, G., De Witte, H., \& Van Hootegem, G. (2012). Job Design, Work Engagement and Innovatiove Work Behavior: One Size Does Not Fit All Types of Employee. Journal of Entrepreneurship, Management and Innovation. Vol 8 (4): 5-20.

Tims, M., Bakker, A.B., \& Xanthopoulou, D. (2011). Do Transformational Leader Enhance Their Followers' Daily Work Engagement?, The Leadership Quartely. Vol. 22: 121-131.

Yuan, F., \& Woodman, R. W. (2010). Innovative Behavior In The Workplace: The Role Of Performance And Image Outcome Expectations. Academy of Management Journal. Vol. 53(2): 323-342. doi: https://doi.org/10.5465/amj.2010.49388995. 
Zhang, X., \& Bartol, K. M. (2010). Linking Empowering Leadership And Employee Creativity: The Influence Of Psychological Empowerment, Intrinsic Motivation, And Creative Process Engagement. Academy of Management Journal. Vol. 53(1): 107-128. doi: https://doi.org/10.5465/amj.2010.48037118. 